$\begin{array}{ll}\text { Research Square } & \begin{array}{l}\text { Preprints are preliminary reports that have not undergone peer review. } \\ \text { They should not be considered conclusive, used to inform clinical practice, } \\ \text { or referenced by the media as validated information. }\end{array}\end{array}$

\title{
A meta-analysis on the curative effect and safety of high-dose flurbiprofen axetil for pain management after general surgery
}

\author{
Tingting Hou \\ Xijing Hospital \\ Dandan Cheng \\ Xijing Hospital \\ Huang Nie ( $\square$ Niehuang@163.com ) \\ Xijing Hospital
}

Research article

Keywords: flurbiprofen axetil, high dose, general surgery, pain management

Posted Date: August 15th, 2019

DOI: https://doi.org/10.21203/rs.2.13043/v1

License: (c) (i) This work is licensed under a Creative Commons Attribution 4.0 International License. Read Full License 


\section{Abstract}

Background To compare the curative efficiency or tolerability of flurbiprofen axetil(FA) in a high dose with that in a standard dose for postoperative pain of general surgery. Methods Relevant RCTs were retrieved from PubMed, Ovid, EMBASE, the Cochrane library, CBM, and CNKI from their inceptions to July 2019. The included studies were selected according to eligibility criteria. The study design, participant characteristics, interventions, and outcomes were abstracted after assessingmethodological quality of the trials. All data were analyzed by Review Manager 5.3. Results 10 studies were identified, which compared the curative effect or tolerability of FA between high and standard dose group. 500 patients were involved in this meta-analysis, with 250 patients in high dose group and 250 patients in standard dose group, respectively. Pooled analysis of VAS scores at $1,2,4,6,8,12$, and $24 \mathrm{~h}$ showed that VAS scores at $1 \mathrm{~h}(\mathrm{P}<0.00001)$, at $2 \mathrm{~h}(P=0.003)$, at $4 \mathrm{~h}(\mathrm{P}=0.0007)$, at $6 \mathrm{~h}(\mathrm{P}=0.0002)$, at $8 \mathrm{~h}(P=$ $0.0002)$, at $12 \mathrm{~h}(P=0.0001)$, and at $24 \mathrm{~h}(P=0.0004)$ in the high dose group were significantly lower than that in the standard group. Pooled analysis of BCS scores at $1,2,4,6,8,12$, and $24 \mathrm{~h}$ showed that BCS scores at $1 \mathrm{~h}(\mathrm{P}<0.00001)$, at $6 \mathrm{~h}(\mathrm{P}<0.00001)$, at 12h $(P=0.03)$, and at 24h $(P=0.01)$ in the high dose group were significantly higher than that in the standard group. Pooled analysis showed that there was no difference in the incidence of adverse events or administrating rate of analgesics after FA treatment between high and standard dose groups $(P>0.05)$. Conclusions In our meta-analysis, we found that FA with high dose $(\geq 1.25 \mathrm{mg} / \mathrm{kg}$ or $100 \mathrm{mg})$ was more effective than that with standard dose in postoperative pain control after general operation, while the incidence of adverse effects with high or standard dose showed no significant difference.

\section{Background}

The treatment of pain is an important concern both for patients and anesthetists. Post-operative pain is caused by direct surgical trauma, and its intensity and range are usually positively correlated with the extent of surgery. Postoperative pain not only affects the living quality of the patients, but also increases the incidence of complications after surgery, and finally delays the recovery of physical function. Therefore, effective analgesic therapy becomes an integral part of treating a 'perioperative disease'

As a nonselective cyclooxygenase (COX) inhibitor, flurbiprofen axetil (FA) owns a high affinity to the site of surgical incision and inflammatory tissues for being incorporated in lipid micro-balloon spheres. FA exerts their analgesic effect through inhibiting the biosynthesis of prostaglandins, restraining sensitization of the peripheral and central nervous systems[1]. FA, a nonsteroidal anti-inlammatory drug (NSAID), is routinely applied in the control of postoperative pain in clinic. Early published studies have showed that preoperative administration of FA reduces postoperative pain in patients undergoing general surgeries, such as thyroidectomy,cholecystectomy, mastectomy, etc.[2-4]

However, there is no clear definition about the optimal analgesic dose of FA in the management of postoperative pain. Frequently, the recommended dose of FA is $50 \mathrm{mg} /$ injection[5]. Recently, some data from several research showed that FA with larger than the recommended dose were more effective in treating postoperative pain[6-13]. However, incidence of side effects might increase with higher dose, ingestion of larger doses is limited. Currently, the maximal dosage of FA is $250 \mathrm{mg}[14] /$ day $\mathbb{b}$ but the optimal dose for a single injection remains unclear when the total amout of $24 \mathrm{~h}$ is below $250 \mathrm{mg}$. Administrating with FA in doses larger than the recommended $50 \mathrm{mg} / \mathrm{injection}$ hasn't been formally assessed for effectiveness and safety. Toward this end, we set out to compare the efficacy and safety of high versus standard doses of FA in patients undergoing general surgeries.

\section{Methods}

\section{Search for eligible studies}

We identified relevant studies through searching electronic databases of PubMed, Ovid, EMBASE, the Cochrane library, CBM and CNKI using the following keywords: "flurbiprofenaxetil", "dose", "surgery", and "pain" (from their inceptions to July 2019). The reference lists of included articles and relevant reviews were searched manually to find other potentially eligible studies.

\section{Inclusion and exclusion criteria}

Articles were selected on the basis of the following criteria: 1) Randomized controlled trials (RCTs); 2) Comparing the efficacy and tolerability of FA with a high single dose $(\geq 1.25 \mathrm{mg} / \mathrm{kg}$ ) to that with a standard single dose $(50 \mathrm{mg})$ for postoperative pain; 3) Patients who experienced postoperative acute pain after general surgery (including hepatobiliary and pancreatic surgery, gastrointestinal surgery, thyroid surgery, anorectal surgery, breast surgery, and vascular surgery);4) The clinical outcomes of pain intensity were evaluated.

Exclusion criteria were as follows: 1) Studies on breakthrough pain; 2) Studies compared the effiency of FA adiminstrated at different operation period; 3) Studies combined FA preparations; 4) Letters, case reports, editorials or reviews; 5) Studies with incomplete raw data.

\section{Data extraction}


For eligible studies, two reviewers independently extracted data from full-text articles using a predefined form. The following information were collected: First author, year of publication, intervention methods, number of cases, gender ratio, mean age, outcome measures (Visual Analogue Scale (VAS), Bruggrmanncomfort scale (BCS) ), complications and adverse reaction rate and information relevant to trial quality $\ a$ allocation concealment, blinding, ect $\$. Uncertainty in the determination of eligibility was resolved by discussion with the other reviewer. If there were studies which has only one subgroup of the participants met the inclusion criteria, we would only extract data on this subgroup to perform the current meta-analysis.

\section{Study Quality}

Two reviewers independently evaluated the risk of bias using the Cochrane Collaboration tool[15]. The authors estimated the following domains: random sequence generation, allocation concealment, blinding of participants and personnel, blinding of outcome assessment, incomplete outcome data, selective reporting, and other bias. Based on the information extracted from included studies, each domain was assigned as a value of "high risk," "unclear risk," or "low risk." Any disagreements between searchers concerning the eligibility of a trial were resolved by consulting a third reviewer.

\section{Statistical Analysis}

Adverse reaction rate and administration rate of analgetic drug were binary outcome data with odds ratio (OR) and $95 \%$ confidence intervals (Cls). VAS and BCS scores were continuous outcome data with mean difference (MD) and respective $95 \%$. We used the program of the Cochrane Collaboration (Review Manager 5.3) to calculate the summary statistic for each component study. The random effect model or fixed effect model was used for outcomes analyse of continuous or dichotomized variables. When there was no difference between the findings derived from the 2 models, the fixed-effect model was used for the results. This was expected to happen in the absence of significant statistical heterogeneity.

Funnel plots were employed to assess the possibility of publication bias. These plots showed the intervention effect from each study against the respective standard error. A symmetrical plot reveals no bias, and any asymmetry of the plot would suggest publication bias. The sensitivity analysis was performed to test the strength and robustness of pooled results by sequential omission of individual studies.

\section{Results}

Search results and characteristic of included studies

A total of 370 relevant titles were identified through searching databases. Of these, 350 were excluded after reviewing abstracts and titles for being on an unrelated topic; not postoperativepain;or not RCTs. Finally, 19 full text articles were collected, wherein ten studies met the inclusion criteria [713 16-18] (Figure 1). The characteristics of the 10 studies were summarized in Table 1. 500 patients were included in this meta-analysis, including 250 patients in high dose group and 250 patients in standard dose group, respectively.

Assessing risk of bias

The detail of the risk-of-bias assessment of included studies was summarized in Figure 2 and Figure 3 . Seven eligible studies were incorporated for risk bias assessment. In terms of the adequate randomization sequence, all studies were assessed as low risk. However, many relative information in the studies wasn't available, such as allocation concealment and blinding of participants and personnel, blinding of outcome assessment. Nevertheless, the overall methodological quality was generally fair.

VAS scores

VAS scores, at different postoperative time points, were reported in all included studies in this meta-analysis. Pooled analysis of VAS scores at 1,4 , $6,8,12,24$, and $48 \mathrm{~h}$ showed that VAS scores at $1 \mathrm{~h}(\mathrm{MD},-2.48 ; 95 \% \mathrm{Cl},[-3.54,-1.41] ; \mathrm{P} \otimes 0.00001)$, at 2h (MD, -1.48; $95 \% \mathrm{Cl},[-2.47,-0.50] ; \mathrm{P}=0.003)$, at $4 \mathrm{~h}(\mathrm{MD},-1.6295 \% \mathrm{Cl},[-2.56,-0.68] ; \mathrm{P}=0.0007)$, at $6 \mathrm{~h}(\mathrm{MD},-1.99 ; 95 \% \mathrm{Cl},[-3.05,-0.93] ; \mathrm{P}=0.0002)$, at $8 \mathrm{~h}(\mathrm{MD},-1.39 ; 95 \% \mathrm{Cl},[-2.12,-0.65] ; \mathrm{P}=$ 0.0002), at $12 \mathrm{~h}(\mathrm{MD},-1.09 ; 95 \% \mathrm{Cl},[-1.65,-0.53] ; \mathrm{P}=0.0001)$, and at $24 \mathrm{~h}(\mathrm{MD},-0.77 ; 95 \% \mathrm{Cl},[-1.20,-0.34] ; \mathrm{P}=0.0004)$ in the high dose group were significantly lower than that in the standard group(Figure 4). As there was evidence of heterogeneity between the study estimates $\left(I^{2}=90 \%\right)$, the random effects model was used.

BCS scores

BCS scores data, at different postoperative time points, were reported in 3 studies. Pooled analysis of BCS scores at 1, 2, 4, 6, 8, 12, and 24 $\mathrm{h}$ showed that BCS scores at $1 \mathrm{~h}(\mathrm{MD}, 2.15 ; 95 \% \mathrm{Cl},[1.69,2.60] ; \mathrm{P} \otimes 0.00001)$, at $6 \mathrm{~h}(\mathrm{MD}, 1.70 ; 95 \% \mathrm{Cl},[1.03,2.37] ; \mathrm{P} \otimes 0.00001)$, at $12 \mathrm{~h}(\mathrm{MD}, 1.19 ; 95 \%$ $\mathrm{Cl},[0.11,2.26] ; \mathrm{P}=0.03)$, and $24 \mathrm{~h}(\mathrm{MD}, 0.46 ; 95 \% \mathrm{Cl},[0.11,0.81] ; \mathrm{P}=0.01)$ in the high dose group were significantly higher than that in the standard group(Figure 5). While there was no significant difference for the BCS scores at 2, 4, $8 \mathrm{~h}$ between high dose and standard group(P凶0.05). As there was evidence of heterogeneity between the study estimates $\left(I^{2}=84 \%\right)$, the random effects model was used. 
The reported adverse effects were nausea, vomiting, diarrhea, bellyache, and etc. The incidence of adverse effects was available in 3 studies, ranging from $5 \%$ to $25 \%$. Pooled analysis showed that there was no difference in adverse effects after FA treatment between high and standard dose groups (OR, 1.17; 95\% Cl, [0.68, 2.01]; $\mathrm{P}=0.58)$ (Figure 6).

Administrating rate of analgetic drug

The administrating rate of analgeic drug was available in 3 studies. Pooled analysis showed that there was no difference in administrating rate of analgetic drug after FA treatment between high and standard dose groups (OR, 0.57; 95\% $\mathrm{Cl},[0.20,1.65] ; \mathrm{P}=0.30)($ Figure 7$)$.

\section{Discussion}

Up to now, the optimal dosage of FA for preventive analgesia remained uncertain, but 50 mg was chosen as the standard dose in clinical study. Some studies have evaluated postoperative analgesic effect of FA in different doses and presented a dose-related effect[19] [6] [7-13]. In this metaanalysis, we combined all data series about FA in different doses for postoperative control after general surgeries to determine the optimal dosage of FA. Compared with a single study, the study of larger sample size was more likely to get precise conclusions. As far as we know, this study was the first meta-analysis on the topic.

In the meta-analysis, we found that VAS scores in the high dose group were significantly lower than that in the standard group at 1, 2, 4, 6, 8, 12, and $24 \mathrm{~h}$, and BCS scores in the high dose group were significantly higher than that in the standard group at 1, 6, 12, and 24h after FA treatment. No significant difference in adverse effects incidence or administrating rate of analgetic drug was found between high and standard dose groups .

VAS and BCS are frequently used to evaluate the intensity of pain. Our study pointed out that the postoperative analgesic effect of FA in high dose was superior to that of the standard dose. Mikawa $\mathrm{K}$ et al. performed a prospective, randomised, controlled trial of 90 children to reveal that preoperative treatment using $1 \mathrm{mg} / \mathrm{kg}$ flurbiprofen was more effective than that of $0.5 \mathrm{mg} / \mathrm{kg}$ for postoperative pain after paediatric strabismus surgery[19].

In a systematic review, oral flurbiprofen $50 \mathrm{mg}$ was used in acute postoperative pain. The result showed that the number needed to treat (NNT) to benefit for at least $50 \%$ pain relief over 4 to 6 hours was 2.7 (2.3 to 3.3) , and for $100 \mathrm{mg}$ it was 2.5 (2.0 to 3.1) compared with placebo.The incidence of adverse effects in placebo group was not significantly different from that of flurbiprofen $50 \mathrm{mg}$ or $100 \mathrm{mg}$ groups. The results were compatible with a dose response, but the differences weren't significant [20]. Schachtel BP also proposed the dose-response relationship of flurbiprofen lozenges for treating sore throat in 3 dosages (2.5, 5.0, and $12.5 \mathrm{mg})$ [21]. In a recent study by Zhao X et al , the analgesic effect of different doses of flurbiprofen axetil was also analyzed for postoperative analgesia, and the results showed that VAS score and postoperative pain incidence in group with the dose of $150 \mathrm{mg}$ or $200 \mathrm{mg}$ was lower than those in the dose of $100 \mathrm{mg}$. Group with the dose of $150 \mathrm{mg}$ had better analgesic effect and lower incidence of adverse reactions[22].

\section{Conclusions}

In the meta-analysis, we demonstrated that the postoperative analgesia in the high dose provided by $1.25-2$ mg/kg FA was superior to that of standard dose, and the side-effects were comparable.

\section{Limitation}

Our study has some limitations. Firstly, the quality of included studies was low. Secondly, publication bias was existed, for all included studies were from China. Further clinical trials with high quality were needed to restate the significant dose response and to confirm that using a higher dose provides additional benefit. Despite these weaknesses, this systematic review can still provide some value for clinical practice.

\section{List Of Abbreviations}

FA: flurbiprofen axetil

cox: cyclooxygenase

NSAID: nonsteroidal anti-inlammatory drug

RCTs: Randomized controlled trials

VAS: Visual Analogue Scale

BCS: Bruggrmanncomfort scale 
OR: odds ratio

Cls: confidence intervals

MD: mean difference

NNT: number needed to treat

\section{Declarations}

Ethics approval and consent to participate

No applicable.

Consent for publication

No applicable.

Competing interests

The authors delare that they have no competing interests.

\section{References}

1. Yamazaki Y, Sonoda H, Seki S. [Effects of preoperatively administered flurbiprofen axetil on the action of inhaled anesthesia and postoperative pain]. Masui The Japanese journal of anesthesiology 1995;44(9):1238-41

2. Gu XJ, Zhong TD. [The effect of flurbiprofen axetil on laparoscopic cholecystectomy]. Zhonghua yi xue za zhi 2010;90(11):760-2

3. Wen Y, Wang M, Yang J, et al. A Comparison of Fentanyl and Flurbiprofen Axetil on Serum VEGF-C, TNF-alpha, and IL-1ss Concentrations in Women Undergoing Surgery for Breast Cancer. Pain Pract 2015;15(6):530-7 doi: 10.1111/papr.12206[published Online First: Epub Date]|.

4. Mao X, Tan X, Zhu X. The effect and care of flurbiprofen axetil injection in patients undergoing thyroidectomy. Modern Clinical Nursing 2007;6(4):62-64

5. Wu H, Chen Z, Sun G, et al. Intravenous flurbiprofen axetil can increase analgesic effect in refractory cancer pain. Journal of experimental \& clinical cancer research : CR 2009;28:33 doi: 10.1186/1756-9966-28-33[published Online First: Epub Date]|.

6. Lu G, Lin C, Chen X, et al. A study on the mechanism related to preoperative analgesia with flurbiprofen axetil in rats with incisional pain. $\mathrm{J}$ Clin Anesthesiol 2009;25(9):800-02

7. Liu Y. Preemptive Analgesic effect of difference dose flurbiprofen axetil in subtotal thyroidectomy. Hei Long Jiang Medical Journal 2010;34(11):811-14

8. Zhang R, Chen J, Wang N, et al. Postoperative analgesic effect of difference dose flurbiprofen axetil in laparoscopic cholecystectomy. J Clin Anesthesiol 2008;24(2):170-71

9. Wang P. Comparison of the postoperative analgesic effect of flurbiprofen axetil with difference dose in thyroidectomy. Chinese Journal of Practical Medicine 2010;37(1)

10. Peng Q. The effect of analgesia and blood coagulation of difference dose flurbiprofen axetil after abdominal operation China Medical Engineering 2012(11):90-90

11. Zhang R, Li D, Wang S. The analgesic effect of difference dose flurbiprofen axetil after modified radical mastectomy. J Clin Anesthesiol 2010;26(2):170-71

12. Li X, Gong H, Zhang Y, et al. Analgesic effect of difference dose of flurbiprofen axetil on postoperative unilateral indirect inguinal herniorrhaphy Journal of Xinxiang Medical College 2014;31(4):278-81

13. Jin L, Ma J, Li J, et al. The analgetic effect of flurbiprofen axetil for larparoscopic cholecystectomy under total intravenous anesthesia. Practical Medical Journal 2008;24(7):1211-13

14. Xu J, Wu X, Luo A, et al. Expert consensus on postoperative pain management in adult patients. J Clin Anesthesiol 2010;26(3):190-96

15. Higgins JP, Altman DG, Gotzsche PC, et al. The Cochrane Collaboration's tool for assessing risk of bias in randomised trials. Bmj 2011;343:d5928 doi: 10.1136/bmj.d5928[published Online First: Epub Date]|.

16. Jin P. The effect of different doses of flurbiprofen axetil injection on the analgesia and inflammatory cytokine levels in patients with differentiated thyroid cancer. J Bengbu Med Coll 2017;42(6):761-63

17. Yang QMXGLDLCYRT. Effects of Different Doses of Flurbiprofen Axetil on Analgesia Effects of Patients after Laparoscopic Cholecystectomy. China Pharmacy 2016;27(8):1085-87 
18. Luo X, Lv F, Peng M. Analgesic effect of different dosage of Flurbiprofen axetil in laparoscopic cholecystectomy in comparison with other analgesic drugs. Pakistan Journal of Pharmaceutical Sciences 2017;30(5(Special)):1895-98

19. Mikawa K, Nishina K, Maekawa N, et al. Dose-response of flurbiprofen on postoperative pain and emesis after paediatric strabismus surgery. Canadian journal of anaesthesia = Journal canadien d'anesthesie 1997;44(1):95-8 doi: 10.1007/BF03014332[published Online First: Epub Date]|.

20. Sultan A, McQuay HJ, Moore RA, et al. Single dose oral flurbiprofen for acute postoperative pain in adults. The Cochrane database of systematic reviews 2009(3):CD007358 doi: 10.1002/14651858.CD007358.pub2[published Online First: Epub Date]|.

21. Schachtel BP, Homan HD, Gibb IA, et al. Demonstration of dose response of flurbiprofen lozenges with the sore throat pain model. Clinical pharmacology and therapeutics 2002;71(5):375-80 doi: 10.1067/mcp.2002.124079[published Online First: Epub Date]|.

22. Zhao X, Ji L. Flurbiprofen axetil: Analgesic effect and adverse reaction. Pakistan Journal of Pharmaceutical Sciences 2018:1163-67

\section{Table}

Table 1. The basic characteristic of included studies

\begin{tabular}{|c|c|c|c|c|c|c|c|c|c|}
\hline $\begin{array}{l}\text { Included } \\
\text { studies }\end{array}$ & $\begin{array}{c}\text { Study } \\
\text { design }\end{array}$ & Age & Weight(kg) & $\begin{array}{l}\text { Sex(male/ } \\
\text { Female) }\end{array}$ & $\begin{array}{c}\text { Sample } \\
\text { size }\end{array}$ & Doses & $\underset{\text { time }}{\text { Administration }}$ & $\begin{array}{c}\text { Sugerical } \\
\text { procedures }\end{array}$ & Outcomes \\
\hline $\begin{array}{l}\text { Yiping } \\
\text { Liu et al } \\
2010\end{array}$ & RCT & $\begin{array}{r}45.40 \pm 10.96: \\
47.30 \pm 8.52\end{array}$ & $\begin{array}{c}65.75 \pm 10.79: \\
61.65 \pm 11.31\end{array}$ & $\begin{array}{l}\text { 1/19: } \\
2 / 18\end{array}$ & $20: 20$ & $\begin{array}{c}1.25 \\
\mathrm{mg} / \mathrm{kg}: \\
0.75 \\
\mathrm{mg} / \mathrm{kg}\end{array}$ & $\begin{array}{c}5 \text { min before } \\
\text { the } \\
\text { intravenous } \\
\text { induction }\end{array}$ & $\begin{array}{c}\text { Subtotal } \\
\text { thyroidectomy }\end{array}$ & $\begin{array}{c}\text { VAS, BCS } \\
\text { at 2, 4, 8, } \\
16,24, \\
48 \mathrm{~h}, \\
\text { adverse } \\
\text { effects }\end{array}$ \\
\hline $\begin{array}{l}\text { Xiaofang } \\
\text { Li et al } \\
2014\end{array}$ & RCT & $\begin{array}{l}4.7 \pm 1.5: \\
4.5 \pm 1.4\end{array}$ & $\begin{array}{l}16.5 \pm 6.5: \\
16.6 \pm 6.5\end{array}$ & $\begin{array}{l}\text { 11/9: } \\
10 / 10\end{array}$ & $20: 20$ & $\begin{array}{c}1.5 \\
\mathrm{mg} / \mathrm{kg}: \\
0.5 \\
\mathrm{mg} / \mathrm{kg}\end{array}$ & $\begin{array}{l}15 \text { min before } \\
\text { surgery }\end{array}$ & $\begin{array}{c}\text { unilateral } \\
\text { indirect } \\
\text { inguinal } \\
\text { herniorrhaphy }\end{array}$ & $\begin{array}{c}\text { VAS at } 2, \\
4,6,8, \\
12 \mathrm{~h}, \\
\text { heart } \\
\text { rate, } \\
\text { respire } \\
\text { rate, } \\
\text { adverse } \\
\text { effects }\end{array}$ \\
\hline $\begin{array}{l}\text { Ruiqin } \\
\text { Zhang et } \\
\text { al } 2008\end{array}$ & RCT & $20 \square 70$ & $40 \square 80$ & NA & $20: 20$ & $\begin{array}{c}1.25 \\
\mathrm{mg} / \mathrm{kg}: \\
0.75 \\
\mathrm{mg} / \mathrm{kg}\end{array}$ & $\begin{array}{l}15 \text { min before } \\
\text { surgery }\end{array}$ & $\begin{array}{c}\text { Laparoscopic } \\
\text { cholecystectomy }\end{array}$ & $\begin{array}{c}\text { VAS, BCS } \\
\text { at } 1,3,6, \\
12 \mathrm{~h}, \\
\text { adverse } \\
\text { effects }\end{array}$ \\
\hline $\begin{array}{l}\text { Ruiqin } \\
\text { Zhang et } \\
\text { al } 2010\end{array}$ & RCT & $\begin{array}{r}46.05 \pm 7.21: \\
48.88 \pm 10.73\end{array}$ & $\begin{array}{l}59.30 \pm 8.65: \\
63.55 \pm 9.53\end{array}$ & NA & $20: 20$ & $\begin{array}{c}1.25 \\
\mathrm{mg} / \mathrm{kg}: \\
0.75 \\
\mathrm{mg} / \mathrm{kg}\end{array}$ & $\begin{array}{l}10 \text { min before } \\
\text { surgery }\end{array}$ & $\begin{array}{l}\text { Modified } \\
\text { radical } \\
\text { mastectomy }\end{array}$ & $\begin{array}{c}\text { VAS, BCS } \\
\text { at } 1,2,4, \\
6,8,12, \\
24 \mathrm{~h}, \\
\text { adverse } \\
\text { effects }\end{array}$ \\
\hline $\begin{array}{l}\text { Qingxiong } \\
\text { Peng et al } \\
\quad 2012\end{array}$ & RCT & NA & NA & NA & $30: 30$ & $\begin{array}{c}\text { 100mg: } \\
50 \mathrm{mg}\end{array}$ & Before surgery & $\begin{array}{l}\text { Abdominal } \\
\text { operation }\end{array}$ & $\begin{array}{l}\text { VASJ, } \\
\text { VASH at } \\
2,4,8 \\
24,48 \mathrm{~h}\end{array}$ \\
\hline $\begin{array}{l}\text { Lexiao Jin } \\
\text { et al } 2008\end{array}$ & RCT & $\begin{array}{c}42.9 \pm 9.5: 44.5 \\
\pm 9.1\end{array}$ & $\begin{array}{l}60.3 \pm 6.3: \\
56.7 \pm 6.7\end{array}$ & $\begin{array}{l}\text { 11/9: } \\
8 / 12\end{array}$ & $20: 20$ & $\begin{array}{c}2 \\
\mathrm{mg} / \mathrm{kg}: \\
1 \mathrm{mg} / \mathrm{kg}\end{array}$ & $\begin{array}{l}\text { Administrated } \\
\text { when VAS } \\
\text { score of } \\
\text { postoperative } \\
\text { pain reached } \\
\text { to } 7\end{array}$ & $\begin{array}{l}\text { larparoscopic } \\
\text { cholecystectomy }\end{array}$ & $\begin{array}{c}\text { VAS at } 3, \\
6,9,12, \\
15,20, \\
30 \text { min, } \\
1,4,8, \\
12,24 \mathrm{~h}, \\
\text { adverse } \\
\text { effects }\end{array}$ \\
\hline $\begin{array}{l}\text { Peishan } \\
\text { Wang et } \\
\text { al } 2010\end{array}$ & RCT & $20 \square 50$ & $40 \square 80$ & NA & $20: 20$ & $\begin{array}{c}1.25 \\
\mathrm{mg} / \mathrm{kg}: \\
0.75 \\
\mathrm{mg} / \mathrm{kg}\end{array}$ & $\begin{array}{l}15 \text { min before } \\
\text { surgery }\end{array}$ & Thyroidectomy & $\begin{array}{c}\text { VAS at } 1, \\
4,8, \\
12,16, \\
24 \mathrm{~h}, \\
\text { adverse } \\
\text { effects }\end{array}$ \\
\hline $\begin{array}{l}\text { Ping Jin } \\
\text { et al } 2017\end{array}$ & RCT & $36 \square 77$ & NA & NA & $30: 30$ & $\begin{array}{c}1.5 \\
\mathrm{mg} / \mathrm{kg}: \\
0.5 \\
\mathrm{mg} / \mathrm{kg}\end{array}$ & $\begin{array}{l}\text { End of } \\
\text { anesthesia } \\
\text { induction }\end{array}$ & $\begin{array}{l}\text { Differentiated } \\
\text { thyroid cancer } \\
\text { surgery }\end{array}$ & \\
\hline $\begin{array}{l}\text { Qian Miao } \\
\text { et al } 2016\end{array}$ & RCT & $\begin{array}{l}41.8 \pm 13.3: \\
40.8 \pm 13.2\end{array}$ & NA & $\begin{array}{c}\text { 21/19: } \\
11 / 9\end{array}$ & $40: 40$ & $\begin{array}{l}\text { 200mg: } \\
100 \mathrm{mg}\end{array}$ & After surgery & $\begin{array}{c}\text { Laparoscopic } \\
\text { cholecystectomy }\end{array}$ & \\
\hline $\begin{array}{l}\text { Xi Luo et } \\
\text { al } 2017\end{array}$ & RCT & $\begin{array}{l}41.02 \pm 6.14: \\
43.59 \pm 5.72\end{array}$ & $\begin{array}{l}63.12 \pm 7.52: \\
64.73 \pm 8.55\end{array}$ & $\begin{array}{l}\text { 15/15: } \\
17 / 13\end{array}$ & $30: 30$ & $\begin{array}{l}\text { 100mg: } \\
50 \mathrm{mg}\end{array}$ & $\begin{array}{l}\text { Before skin } \\
\text { incision } 15 \mathrm{~min}\end{array}$ & $\begin{array}{l}\text { Laparoscopic } \\
\text { cholecystectomy }\end{array}$ & \\
\hline
\end{tabular}

\section{Figures}





Figure 1

Flow chart displaying the selection details of included studies

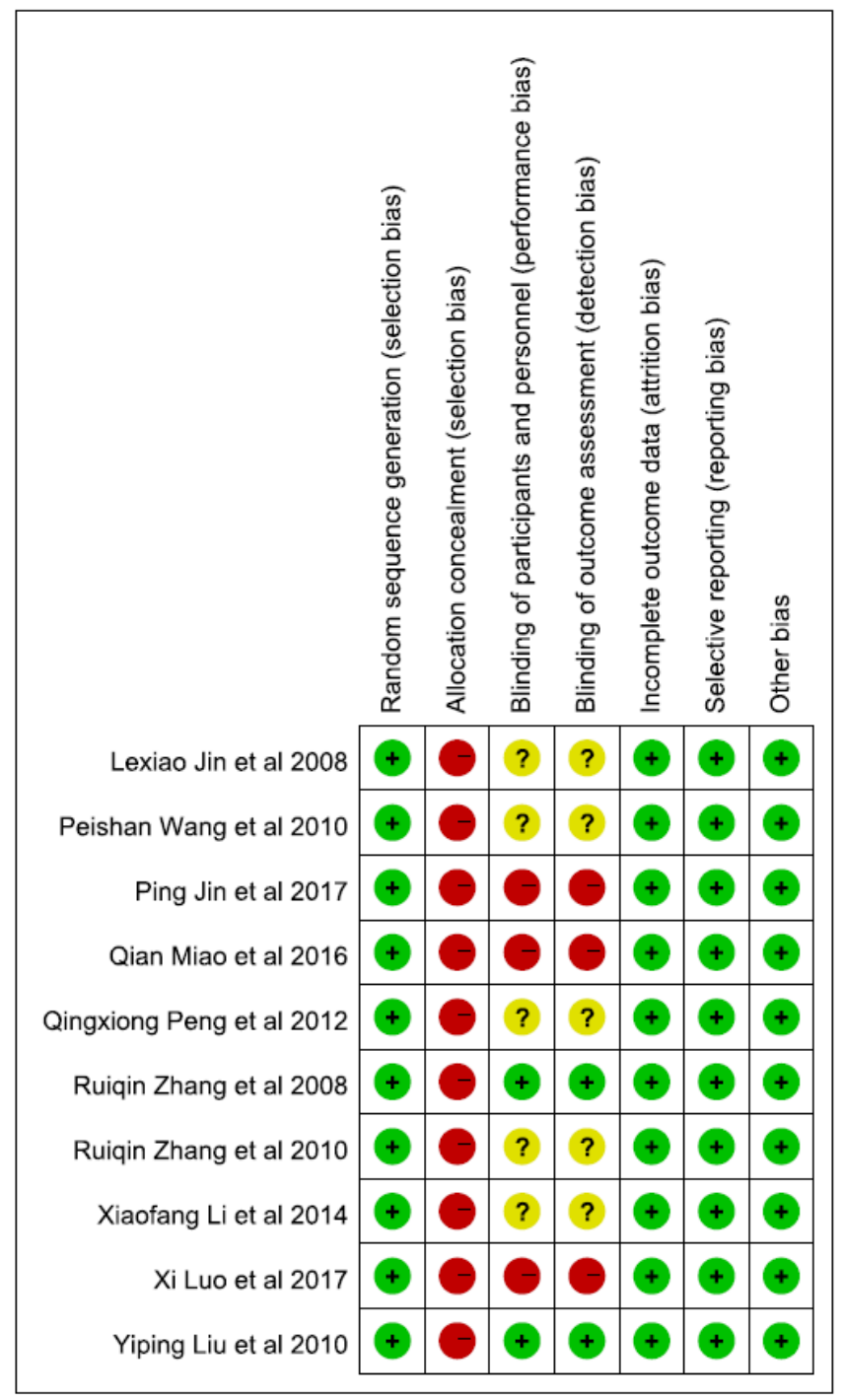




\section{Figure 2}

Risk of bias summary of included study. Low risk = bias, if present, is unlikely to alter the results seriously, unclear risk = bias raises some doubt about the results, high risk = bias may alter the results seriously.

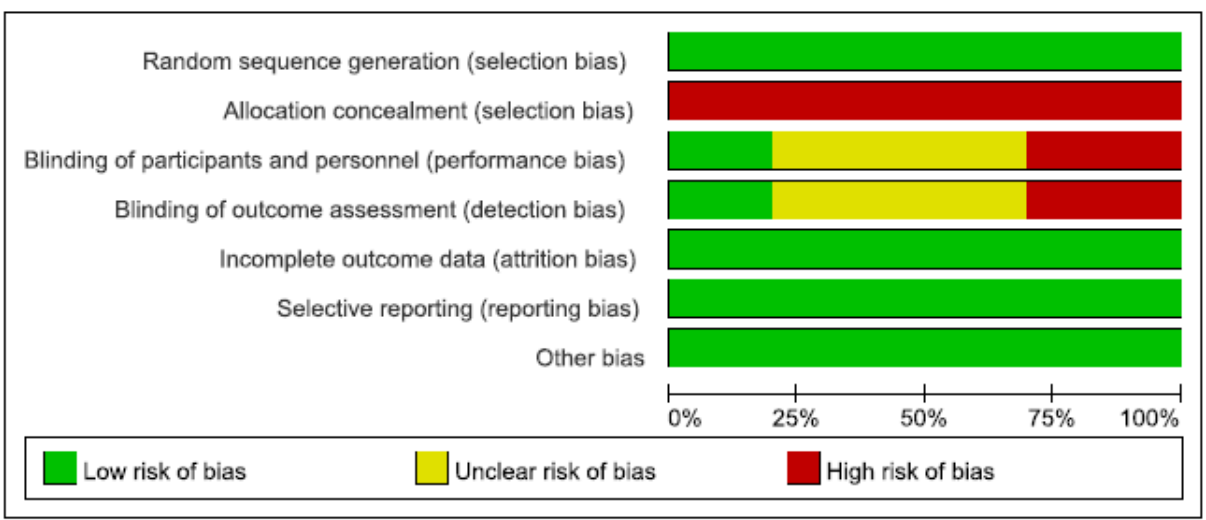

\section{Figure 3}

Risk of bias graph across all included studies

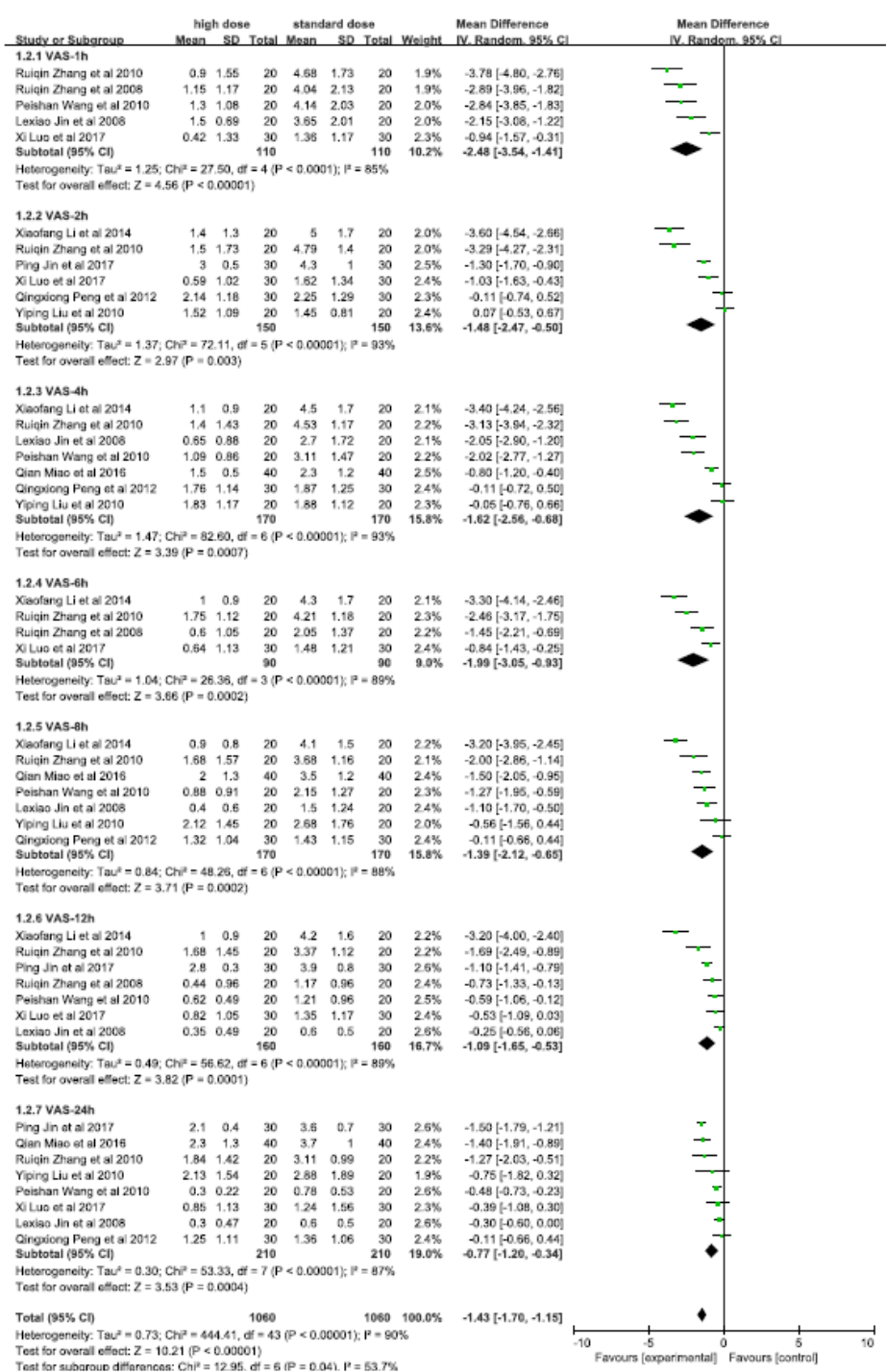

\section{Figure 4}

Meta-analysis of VAS score between the high dose group and standard group 


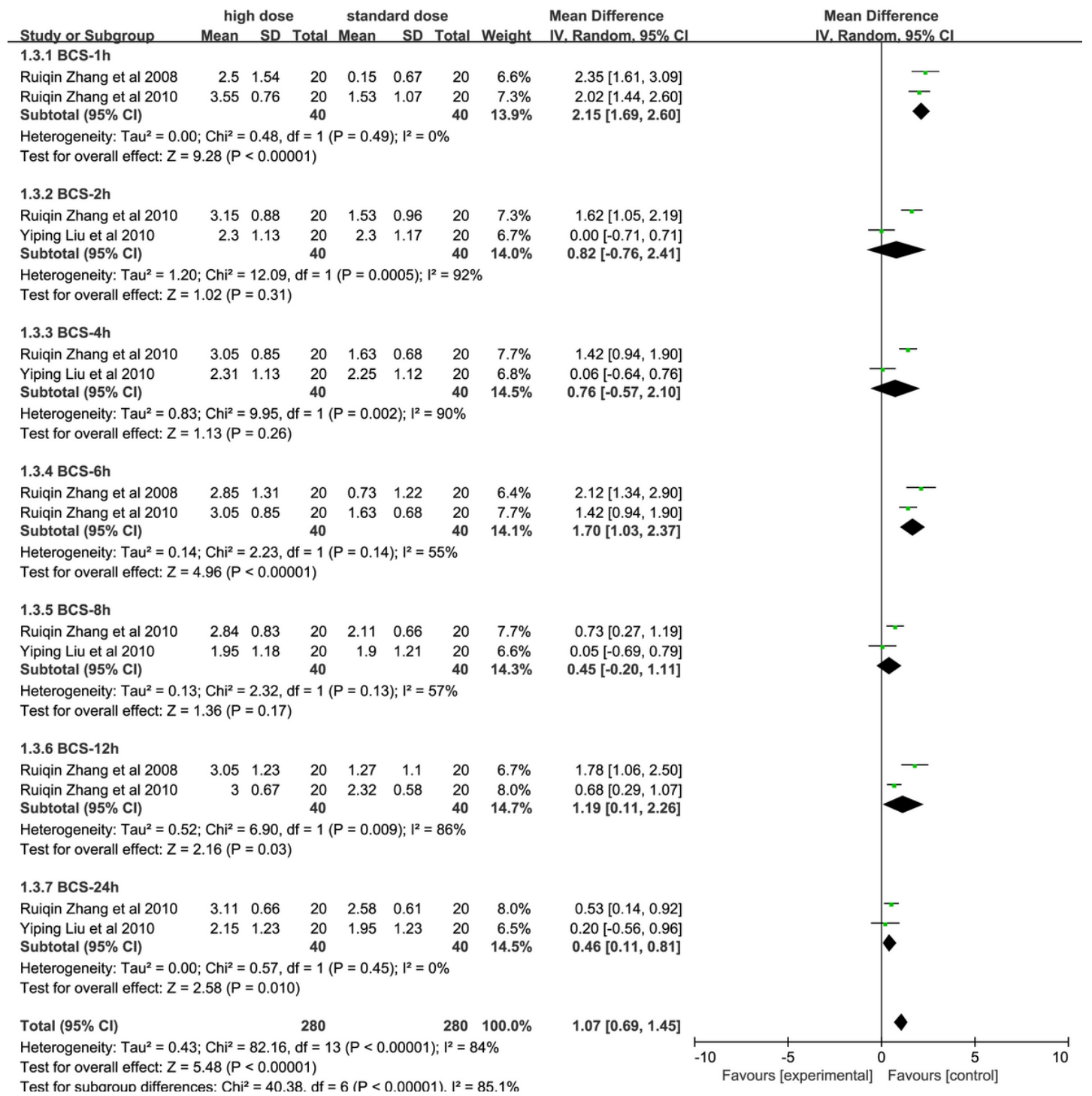

\section{Figure 5}

Meta-analysis of BCS score between the high dose group and standard group

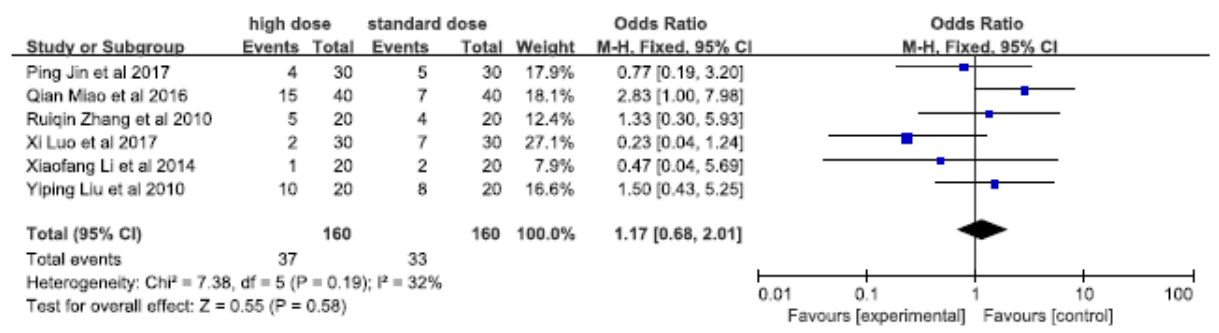

\section{Figure 6}

Meta-analysis of adverse reaction rate between the high dose group and standard group 


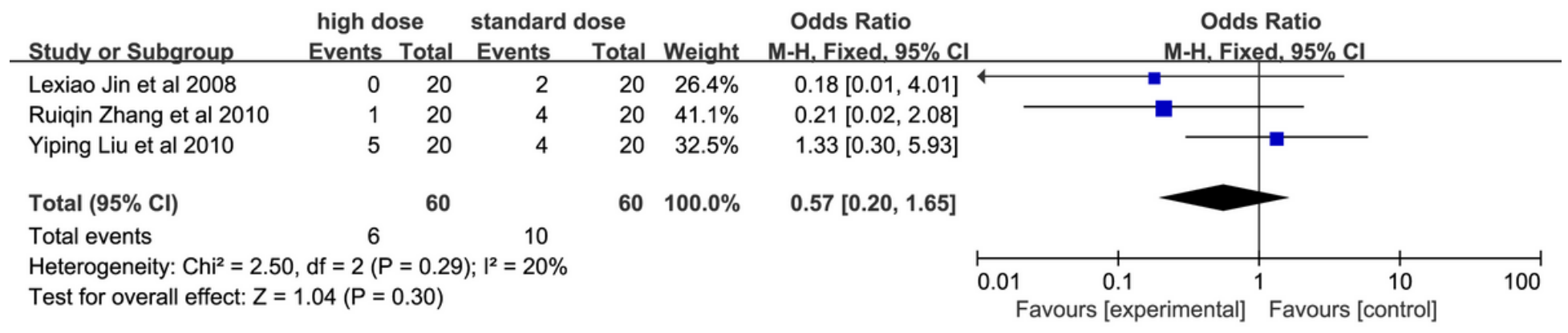

\section{Figure 7}

Meta-analysis of the administration rate of analgetic drug rate between the high dose group and standard group

\section{Supplementary Files}

This is a list of supplementary files associated with this preprint. Click to download.

- PRISMAguidelines.pdf 